A

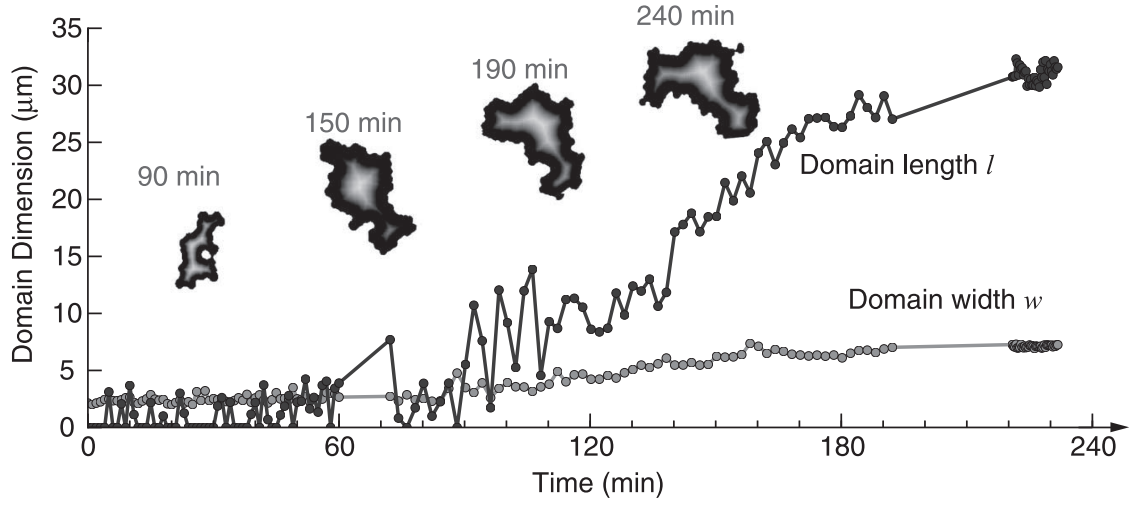

B

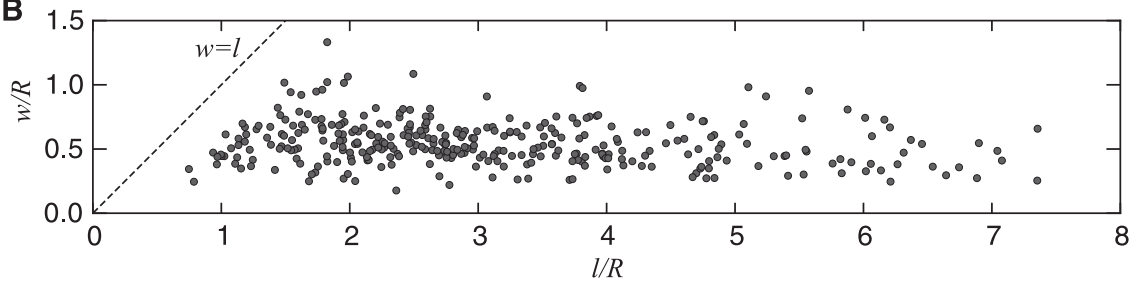

Fig. 4. (A) Measurements of domain length $l$ (black) and width $w$ (gray) as a function of time for a droplet with $R=18 \mu \mathrm{m}$ (18). Images of domain morphologies at various times are shown at top (see also movie S1). The transition from isotropic to anisotropic growth occurs at about $100 \mathrm{~min}$. (B) Distribution of $l$ and $w$, both normalized to the radius of curvature $R$, for curved crystals. The dashed line marks the isotropic regime where $w=l . w / R$ is roughly constant, in agreement with the model.

particularly relevant to nanoscale substrates, where the curvature is appreciable on molecular length scales. For example, solid domains consisting of narrow stripes radiating outward from a circular core have been observed in diverse systems, such as phases on lipid vesicles (17) and metal coatings on nanoparticles (14). Our analysis suggests that the width of the stripes and the core size should be determined by the interplay among curvature, elasticity, and bulk energy. A similar interplay may affect the assembly pathways of viral capsids. Recent in vitro experiments (26) show that capsids can assemble following a two-step mechanism analogous to our crystallization process: The capsid proteins first attach to a substrate (an RNA molecule) and then bind together into an ordered shell. The intermediate states of this process - long a subject of speculation (11) - might contain voids that, like those in our curved crystals, help the capsids avoid excess elastic stress $(27,28)$.

Similar rules may govern other crystallization and packing problems where global geometry is incompatible with local lattice packing. For example, crystallization of tetrahedra is frustrated in flat (Euclidean) 3D space (6). However, logs and helices of tetrahedra are prevalent in first-order phase transitions of tetrahedra from disordered to dense quasicrystalline phases (7). The existence of these structures, which were first described by Bernal (29), may reflect a similar physical principle, in which growth along one dimension allows a crystal to escape the restrictions of geometrical frustration.

References and Notes

1. N. Steno, The Prodromus of Nicolaus Steno's Dissertation Concerning a Solid Body Enclosed by Process of Nature Within a Solid; an English Version with an Introduction and Explanatory Notes by John Garrett Winter (Macmillan, London, 1916)

2. I. Sunagawa, Crystals: Growth, Morphology, \& Perfection (Cambridge Univ. Press, Cambridge, 2005).

3. A. T. Skjeltorp, Phys. Rev. Lett. 58, 1444-1447 (1987)

4. J. S. Langer, Rev. Mod. Phys. 52, 1-28 (1980).

5. K. G. Libbrecht, Rep. Prog. Phys. 68, 855-895 (2005).

6. D. Nelson, F. Spaepen, Solid State Phys. 42, 1 (1989).

7. A. Haji-Akbari et al., Nature 462, 773-777 (2009).

8. A. R. Bausch et al., Science 299, 1716-1718 (2003).

9. P. Lipowsky, M. J. Bowick, ]. H. Meinke, D. R. Nelson, A. R. Bausch, Nat. Mater. 4, 407-411 (2005).

10. W. T. M. Irvine, V. Vitelli, P. M. Chaikin, Nature 468, 947-951 (2010)
11. W. H. Roos, R. Bruinsma, G. J. L. Wuite, Nat. Phys. 6 , 733-743 (2010).

12. I. R. Bruss, G. M. Grason, Proc. Natl. Acad. Sci. U.S.A. 109, 10781-10786 (2012).

13. G. A. DeVries et al., Science 315, 358-361 (2007).

14. H. Bao, W. Peukert, R. Klupp Taylor, Adv. Mater. 23, 2644-2649 (2011).

15. R. Lipowsky, Nature 349, 475-481 (1991)

16. J. Korlach, P. Schwille, W. W. Webb, G. W. Feigenson, Proc. Natl. Acad. Sci. U.S.A. 96, 8461-8466 (1999).

17. A. Bandekar, S. Sofou, Langmuir 28, 4113-4122 (2012).

18. See supplementary materials on Science Online.

19. W. W. Mullins, R. F. Sekerka, J. Appl. Phys. 34, 323 (1963).

20. W. W. Mullins, R. F. Sekerka, J. Appl. Phys. 35, 444 (1964).

21. S. Schneider, G. Gompper, Europhys. Lett. 70, 136-142 (2005).

22. A. Y. Morozov, R. F. Bruinsma, Phys. Rev. E 81, 041925 (2010).

23. Y. Chushak, A. Travesset, Europhys. Lett. 72, 767-773 (2005).

24. D. R. Nelson, Defects and Geometry in Condensed Matter Physics (Cambridge Univ. Press, Cambridge, 2002).

25. C. Majidi, R. S. Fearing, Proc. R. Soc. London Ser. A 464, 1309 (2008).

26. R. F. Garmann, M. Comas-Garcia, A. Gopal, C. M. Knobler, W. M. Gelbart, J. Mol. Biol. 10.1016/j.jmb.2013.10.017 (2013).

27. W. S. Klug, W. H. Roos, G. J. Wuite, Phys. Rev. Lett. 109 168104 (2012)

28. A. Luque, D. Reguera, A. Morozov, J. Rudnick, R. Bruinsma, J. Chem. Phys. 136, 184507 (2012).

29. J. D. Bernal, Proc. R. Soc. London Ser. A 280, 299-322 (1964).

30. S. Asakura, F. Oosawa, J. Chem. Phys. 22, 1255 (1954).

31. R. Roth, B. Götzelmann, S. Dietrich, Phys. Rev. Lett. 83, 448-451 (1999).

Acknowledgments: We thank F. Spaepen for helpful discussions. Supported by the Harvard Materials Research Science and Engineering Center through NSF grant DMR-0820484.

\section{Supplementary Materials}

www.sciencemag.org/content/343/6171/634/suppl/DC1

Materials and Methods

Figs. $\mathrm{S} 1$ to $\mathrm{S} 4$

References (32-58)

Movies S1 to S4

19 August 2013; accepted 7 January 2014

$10.1126 /$ science. 1244827

\title{
Rapid Soil Production and Weathering in the Southern Alps, New Zealand
}

Isaac ]. Larsen, ${ }^{1 *} \dagger$ Peter C. Almond, ${ }^{2}$ Andre Eger, ${ }^{2} \ddagger$ John 0. Stone, ${ }^{1}$

David R. Montgomery, ${ }^{1}$ Brendon Malcolm ${ }^{2}$

Evaluating conflicting theories about the influence of mountains on carbon dioxide cycling and climate requires understanding weathering fluxes from tectonically uplifting landscapes. The lack of soil production and weathering rate measurements in Earth's most rapidly uplifting mountains has made it difficult to determine whether weathering rates increase or decline in response to rapid erosion. Beryllium-10 concentrations in soils from the western Southern Alps, New Zealand, demonstrate that soil is produced from bedrock more rapidly than previously recognized, at rates up to 2.5 millimeters per year. Weathering intensity data further indicate that soil chemical denudation rates increase proportionally with erosion rates. These high weathering rates support the view that mountains play a key role in global-scale chemical weathering and thus have potentially important implications for the global carbon cycle.

$\mathrm{P}$ late tectonics has long been thought to influence climate through links among rock uplift, relief generation, erosion, silicate weathering, and $\mathrm{CO}_{2}$ cycling $(1,2)$. Determin- ing the form of the functional relationship between hillslope erosion and weathering rates is critical for understanding how or if mountains influence global weathering budgets and climate 
(3-6). Current models predict that soil weathering is supply-limited and dependent on the supply of fresh minerals when erosion rates are low, but that weathering becomes increasingly kinetically limited as erosion rates increase, due to reduced mineral residence times in the soil (3-5). However, there are few observational constraints on soil production and soil weathering rates in Earth's most rapidly uplifting mountains, and it is unclear whether chemical weathering rates continue to increase or decline as erosion rates increase beyond about 100 metric tons $\mathrm{km}^{-2}$ year $^{-1}$ $\left(\sim 0.04 \mathrm{~mm}\right.$ year $\left.^{-1}\right)(6)$.

We determined soil production and catchmentscale denudation rates by measuring concentrations of in situ-produced ${ }^{10} \mathrm{Be}$ in soil and sediment, respectively, and inferred chemical denudation rates using $\mathrm{Zr}$ mass balance (7) in the western Southern Alps of New Zealand (Fig. 1). The study sites are located east of the Alpine Fault, where rock uplift, exhumation, and erosion rates reach $10 \mathrm{~mm}$ year $^{-1}(8-11)$ and watershed-scale weathering fluxes are extremely high (12). Mean annual precipitation exceeds $10 \mathrm{~m}_{\text {year }}{ }^{-1}$, supporting dense temperate montane rainforest and subalpine shrub ecosystems that grow on $<1$-m-thick soils formed from highly fractured schist (13-15).

Soil production rates on ridgetops range from 0.1 to $2.5 \mathrm{~mm}$ year $^{-1}$ and decline exponentially with increasing soil thickness at two of the three sites with a sufficient number of samples $(n \geq 5)$ to define a regression relationship (Fig. 2A). The form of these exponentially declining soil production functions is consistent with those determined for other landscapes (16). However, comparison with data compiled from sites worldwide indicates that soil production rates in the western Southern Alps reach levels more than an order of magnitude greater than measured elsewhere (Fig. 2B), demonstrating that soil production can play a far

${ }^{1}$ Department of Earth and Space Sciences and Quaternary Research Center, University of Washington, Seattle, WA 98195-1310, USA. '2Department of Soil and Physical Sciences, Lincoln University, Christchurch 7647 New Zealand.

*Corresponding author. E-mail: larseni@caltech.edu †Present address: Division of Geological and Planetary Sciences, California Institute of Technology, Pasadena, USA. †Present address: Institute of Earth and Environmenta Science, University of Potsdam, Germany. greater role in mountain denudation than previously documented.

Chemical depletion fractions increase with soil thickness (Fig. 2C) and decline with increasing soil production rates (Fig. 2D), which is consistent with declining soil residence times that models predict at high denudation rates (3-5) and measurements from the San Gabriel Mountains (17). However, the high $P$ values preclude concluding that the regression slopes are significantly different from zero. Thus, weathering may be supply-limited at the very high denudation rates we observe. Regardless of whether the chemical denudation data conform to supply- or kinetically limited weathering, the chemical denudation rates inferred from the $\mathrm{Zr}$ and ${ }^{10} \mathrm{Be}$ data increase linearly with physical erosion rates (Fig. 2E). Comparison of our soil chemical denudation rates against a compilation of worldwide data indicates that soil chemical denudation rates in the western Southern Alps are the highest values yet determined, and the power-law scaling exponent of $\sim 1.0$ indicates that chemical denudation rates increase linearly as erosion rates increase by nearly three orders of magnitude (Fig. 3A). The relationship between soil chemical denudation and physical denudation rates observed in the western Southern Alps is consistent with data from more slowly eroding landscapes (18) and extends the range of soil production rates over which weathering and denudation rates increase in proportion to one another to much higher values than previously recognized. If the relationship becomes nonlinear or reverses to an inverse correlation, as predicted by several models (3-5), it does so at rates higher than we observe in the western Southern Alps. Hence, our findings do not support the view that mountains are inefficient sites for weathering because of "speed limits" to soil production and chemical denudation (19); values from the western Southern Alps break the proposed speed limits for both soil production and soil weathering.

${ }^{10} \mathrm{Be}$ concentrations in sediment indicate that total denudation rates for watersheds in the western Southern Alps range from 1 to $9 \mathrm{~mm}_{\text {year }}{ }^{-1}$ (Fig. 1). Small catchments that drain areas within 1 to $2 \mathrm{~km}$ of the Alpine Fault have the lowest denudation rates of 1 to $2 \mathrm{~mm} \mathrm{year}^{-1}$. Larger catchments and subcatchments that drain areas farther to the east of the Alpine Fault denude at rates of 4 to $12 \mathrm{~mm}_{\text {year }}{ }^{-1}$. The spatial pattern of decreasing watershed-scale denudation toward the Alpine Fault is consistent with crustal velocity fields predicted by simple shear deformation (20) and vertical deformation measured by global positioning systems (21).

The maximum soil production rate that we measured in the western Southern Alps equals or exceeds denudation rates for the more slowly eroding watersheds. However, for a given catchment, soil production rates are a fraction of the catchment-averaged denudation rates. Hillslopes below the tree line in the western Southern Alps have very little bedrock exposure, even though soil production rates are lower than catchmentaveraged denudation rates. The landscape maintains a soil mantle because the return interval for landslides, which must account for the balance of catchment-averaged denudation not attributable to soil production (10), is long enough at any point on the landscape that soils develop between failures (22). The soil-mantled hillslopes and high soil production rates in the western Southern Alps indicate that, contrary to previous suggestions (23), hillslopes are not necessarily stripped of soil at high uplift rates. Although strong evidence for a transition from soil-mantled to bedrock hillslopes exists for the San Gabriel Mountains $(22,24)$, mean annual precipitation in the San Gabriel Mountains is an order of magnitude lower than in the western Southern Alps. We suspect that the emergence of bare bedrock hillslopes in tectonically active landscapes is modulated in large part by climate, with soil production able to proceed at higher rates in wetter, and thus more vegetated, regions, such as our study area.

The high mean annual precipitation promotes rapid leaching (14) and supports high annual vegetation productivity (25), which we suggest, along with pervasively fractured bedrock, contribute to the high soil production rates that we observe. The primarily biotic driver of soil production is vegetation, because burrowing mammals, which contribute to soil production in other landscapes (16), are not endemic to New Zealand. Coarse and fine roots readily penetrate bedrock by exploiting foliation planes and fractures generated by tectonics (15) and erosional unloading (fig. S1). Root expansion in fractures, especially
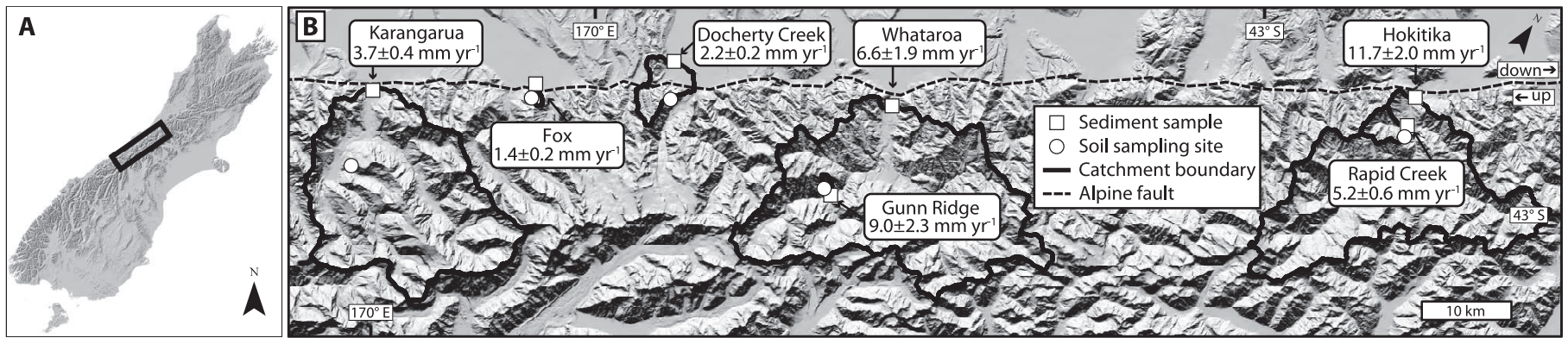

Fig. 1. Study sites. Location of the field area on New Zealand's South Island (A), sample locations, and watershed scale denudation rates ( \pm 1 SE) (B). 
foliation planes within a few $\mathrm{cm}$ of the soilbedrock interface, likely plays a key role in converting rock to soil, both by physically breaking rock and by enhancing chemical weathering through organic acid production and increased subsurface $\mathrm{CO}_{2}$ concentrations.

The high soil production rates in the western Southern Alps are consistent with estimated soil residence times of only a few centuries (14) and rapid weathering and leaching (26) documented at other sites on the South Island's west coast. Soil production rates also increase with watershedscale denudation rates, as observed in more slowly eroding landscapes (22). Soil production rates have not been measured in other mountains undergoing uplift rates comparable to those in the western Southern Alps. However, in the Taiwan orogen, hillslopes are soil-mantled even though landslides - which primarily mobilize soil — erode the landscape at rates $>2 \mathrm{~mm}_{\text {year }}{ }^{-1}$ (27). Similarly, hillslopes in the Tsangpo Gorge of the eastern Himalaya are soil mantled, despite erosion rates $>4$ mm year $^{-1}$ (28), suggesting that soil produc- tion rates in other landscapes are also sufficiently rapid that hillslopes are not stripped to bedrock, despite high rates of rock uplift and erosion.

Global river solute and sediment yield data (29) demonstrate that catchment-averaged chemical denudation rates span a similar range of values as global soil chemical denudation rates, although the power-law scaling exponent less than unity differs from the soils data (Fig. 3B). River solute data indicate that catchment-scale chemical denudation rates in the western Southern Alps are of the same magnitude as soil chemical denudation rates. However, chemical denudation accounts for $<5 \%$ of catchment-scale denudation $(12,30)$. Similarly, the mean soil chemical denudation rates that we determined are 1 to $7 \%$ of the ${ }^{10} \mathrm{Be}$-based total denudation rates determined for each watershed, whereas mean chemical denudation is 16 to $32 \%$ of the soil production rate at each of the ridgetop sites. The differing ratio of chemical to total denudation rates observed for soils versus catchments is likely due to a high proportion of unweathered rock in the debris delivered to rivers by landslides. A more detailed geochemical budget is required to assess weathering fluxes from deep bedrock ( 6 ) and landslide-affected terrain (31), but if soil dynamics at the sites we sampled are at least broadly representative of those occurring throughout the landscape, our results suggest that soil weathering may be an important contributor to the high weathering flux in the western Southern Alps $(12,30,32)$.

The high denudation rates in the western Southern Alps are consistent with global fluxes determined using river load data, which demonstrate that young, wet mountains make up only $14 \%$ of the ocean-draining land area but account for $62 \%$ of sediment, $38 \%$ of total dissolved solid, and $60 \%$ of dissolved silica delivered to Earth's oceans (29). Hillslopes in rapidly uplifting mountains appear to bypass the hypothesized weathering speed limit because high rates of orographic precipitation support ecosystems that physically break up rock and promote weathering and leaching, allowing rapid soil production to contribute to the high orogen-scale weathering fluxes.
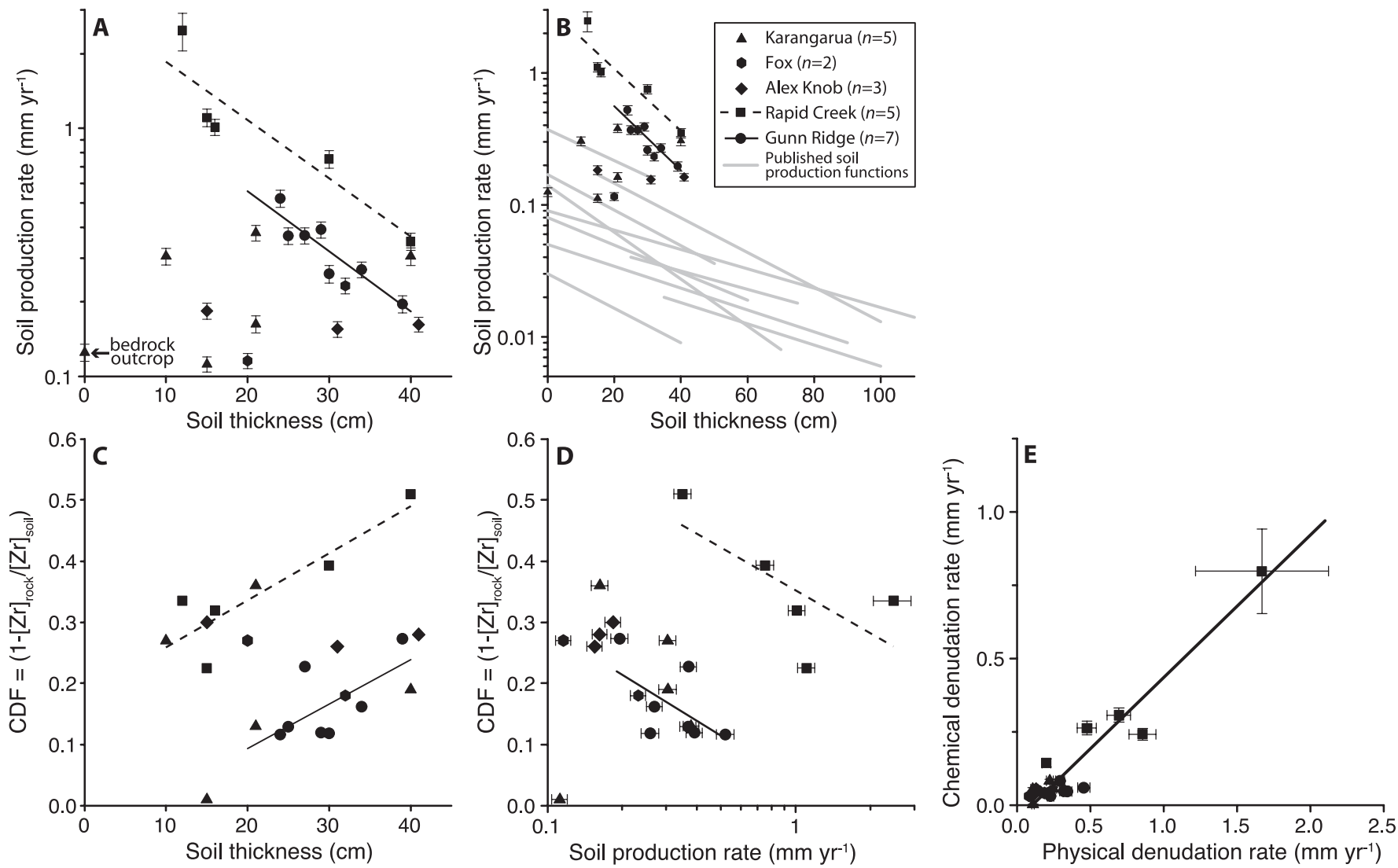

Fig. 2. Soil production rates, chemical depletion data, and chemical versus physical denudation rates. (A) Soil production rate versus soil thickness for the western Southern Alps. Soil production rates decline exponentially with increasing soil thickness at the Gunn Ridge and Rapid Creek sites, and the respective exponential regression fits are $y=1.71(+0.71 /-0.50) \mathrm{e}^{-0.056( \pm 0.012) x}$, $R^{2}=0.82, P=0.005$ and $y=3.18(+1.33 /-0.94) \mathrm{e}^{-0.054( \pm 0.015) x}, R^{2}=0.83, P=0.03$. (B) Western Southern Alps soil production rates and soil production functions plotted with a worldwide compilation of soil production functions; see supplementary materials for data sources. (C) Chemical depletion fraction (CDF) versus soil thickness for the western Southern Alps. CDF values increase with soil thickness as $y=$

$0.0073( \pm 0.0040) x-0.052( \pm 0.12), R^{2}=0.39, P=0.13$ for Gunn Ridge and $y=$ $0.0077( \pm 0.0023) x+0.18( \pm 0.057), R^{2}=0.79, P=0.04$ for Rapid Creek. (D) CDF versus soil production rates for the western Southern Alps. CDF values decline as soil production rates increase, as $y=-0.11( \pm 0.070) \ln (x)+0.036( \pm 0.081), R^{2}=$ $0.35, P=0.16$ for Gunn Ridge and $y=-0.10( \pm 0.062) \ln (x)+0.35( \pm 0.039), R^{2}=$ $0.48, P=0.20$ for Rapid Creek. (E) Chemical denudation rate versus physical denudation rate for the western Southern Alps. Chemical denudation rates increase linearly as physical denudation rates increase. The linear reduced major axis (RMA) regression fit shown by the line is $y=0.49( \pm 0.036) x-0.052( \pm 0.017), R^{2}=0.89, P<$ 0.001 . Error bars and parentheses indicate $\pm 1 \mathrm{SE} ; P$ values based on $t$ statistics. 
Physical denudation rate $\left(\mathrm{mm} \mathrm{yr}^{-1}\right)$
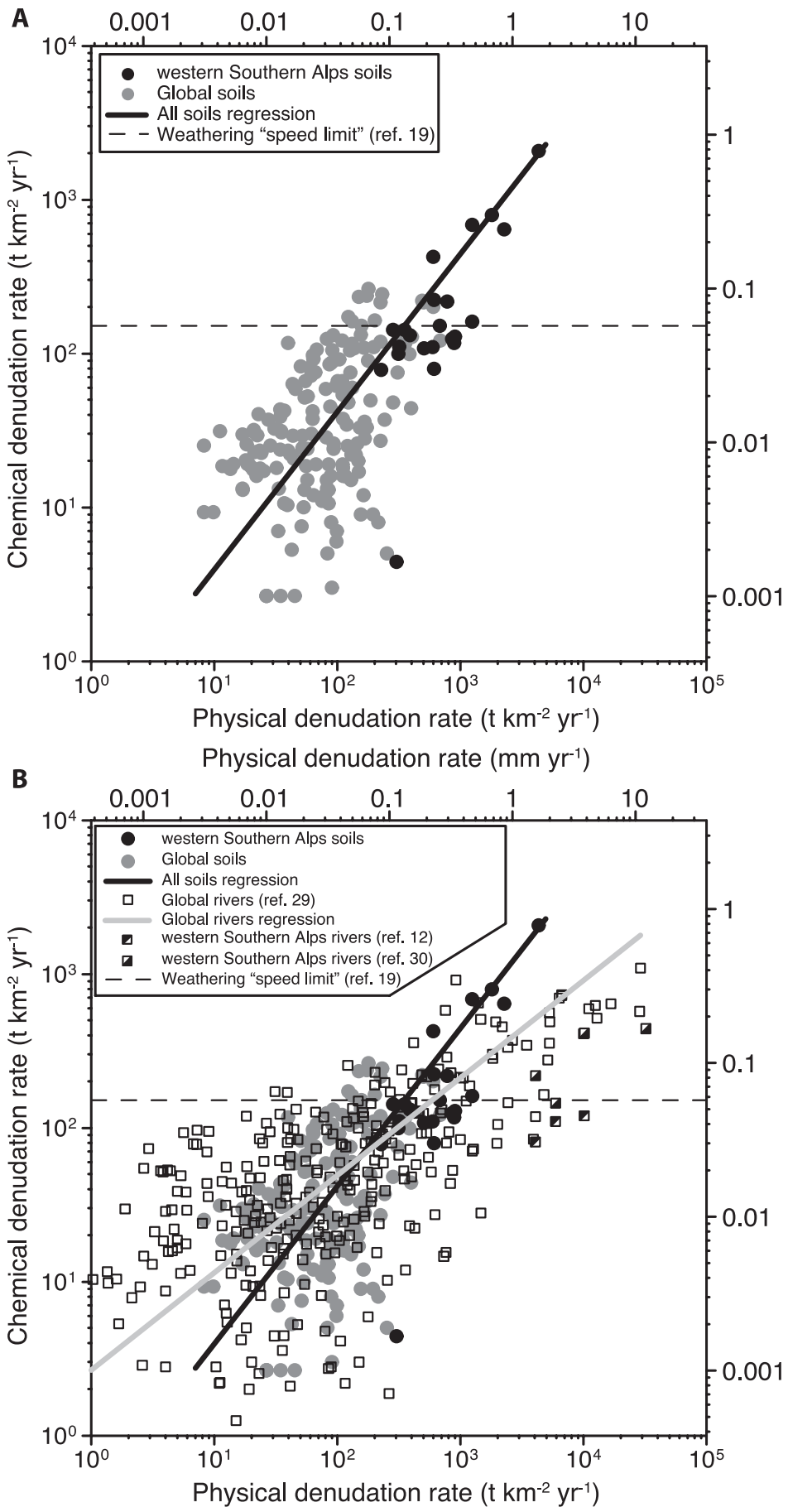

Fig. 3. Chemical versus physical denudation rate for worldwide soil and river data. (A) The RMA power-law fit to the soil mass flux data is $y=0.37(+0.12 /-0.09) x^{1.025( \pm 0.059)}, R^{2}=0.38, P<$ 0.001 , indicating that chemical denudation increases linearly as physical denudation rates increase by nearly three orders of magnitude. (B) The RMA power-law fit to the river mass flux data (29) is $y=2.66(+0.39 /-0.35) x^{0.63( \pm 0.028)}, R^{2}=0.41, P<0.001$. The hypothesized global weathering speed limit (19) (horizontal dashed line) is shown for reference. Also shown are river flux-based denudation data from the western Southern Alps $(11,12,30)$; note that river and soil chemical denudation rates in the western Southern Alps are of similar magnitude. The upper and right axes with length units are related to the mass flux axes by a density of $2.65 \mathrm{~g} \mathrm{~cm}^{-3}$ and thus are approximate and for reference only, because rock density varies among the samples. See supplementary materials for data sources.
References and Notes

1. T. C. Chamberlin, ]. Geol. 7, 545-584 (1899).

2. M. E. Raymo, W. F. Ruddiman, Nature 359, 117-122 (1992)

3. K. L. Ferrier, ]. W. Kirchner, Earth Planet. Sci. Lett. 272, 591-599 (2008).

4. E. J. Gabet, S. M. Mudd, Geology 37, 151-154 (2009).

5. G. E. Hilley, C. P. Chamberlain, S. Moon, S. Porder, S. D. Willett, Earth Planet. Sci. Lett. 293, 191-199 (2010).

6. A. J. West, Geology 40, 811-814 (2012).

7. Materials and methods are available as supplementary materials on Science Online.

8. R. J. Norris, A. F. Cooper, J. Struct. Geol. 23, 507-520 (2001)

9. J. M. Tippett, P. J. J. Kamp, J. Geophys. Res. 98 (B9), 16119-16148 (1993).

10. N. Hovius, C. P. Stark, P. A. Allen, Geology 25, 231-234 (1997)

11. D. M. Hicks et al., J. Hydrol. N.Z. 50, 81-142 (2011).

12. A. D. Jacobson, J. D. Blum, Geology 31, 865-868 (2003).

13. G. A. Griffiths, M. J. McSaveney, N. Z. J. Sci. 26, 197-209 (1983).

14. L. R. Basher, P. J. Tonkin, M. J. McSaveney, Z. Geomorphol. 69, 117-131 (1988)

15. B. A. Clarke, D. W. Burbank, J. Geophys. Res. 116 (F4), F04009 (2011).

16. A. M. Heimsath, W. E. Dietrich, K. Nishiizumi, R. C. Finkel, Nature 388, 358-361 (1997).

17. J. L. Dixon, A. S. Hartshorn, A. M. Heimsath, R. A. DiBiase, K. X. Whipple, Earth Planet. Sci. Lett. 323-324, 40-49 (2012)

18. C. S. Riebe, ]. W. Kirchner, R. C. Finkel, Earth Planet. Sci. Lett. 224, 547-562 (2004).

19. ]. L. Dixon, F. von Blanckenburg, C. R. Geosci. 344, 597-609 (2012).

20. J. Braun, F. Herman, G. Batt, Earth Planet. Sci. Lett. 300, 197-204 (2010).

21. J. Beavan et al., Geophys. Res. Lett. 37, L16305 (2010)

22. A. M. Heimsath, R. A. DiBiase, K. X. Whipple, Nat. Geosci. 5, 210-214 (2012).

23. K. X. Whipple, E. Kirby, S. H. Brocklehurst, Nature 401, 39-43 (1999).

24. R. A. DiBiase, A. M. Heimsath, K. X. Whipple, Earth Surf. Process. Landf. 37, 855-865 (2012).

25. R. G. Hilton, P. Meunier, N. Hovius, P. J. Bellingham, A. Galy, Earth Surf. Process. Landf. 36, 1670-1679 (2011)

26. A. Eger, P. C. Almond, L. M. Condron, Geoderma 163, 185-196 (2011).

27. Z.-X. Tsai, G. ].-Y. You, H.-Y. Lee, Y.-J. Chiu, Earth Surf. Process. Landf. 38, 661-674 (2013).

28. I. ]. Larsen, D. R. Montgomery, Nat. Geosci. 5, 468-473 (2012).

29. ]. D. Milliman, K. L. Farnsworth, River Discharge to the Coastal Ocean: A Global Synthesis (Cambridge Univ. Press, New York, 2011).

30. W. B. Lyons, A. E. Carey, D. M. Hicks, C. A. Nezat J. Geophys. Res. 110 (F1), F01008 (2005).

31. E. Gabet, Earth Planet. Sci. Lett. 264, 259-265 (2007)

32. J. Moore, A. D. Jacobson, C. Holmden, D. Craw, Chem. Geol. 341, 110-127 (2013).

Acknowledgments: We thank the NSF East Asia and Pacific Summer Institutes program (OISE-1015454 to I.].L.), Royal Society of New Zealand, NASA Earth and Space Science fellowship program, Geological Society of America, and University of Washington Department of Earth and Space Sciences for support; A. Heimsath, J. Roering, F. von Blanckenburg, and N. Hovius for stimulating conversations; H. Greenberg for geographic information system support; K. Larsen for assistance collecting sediment samples; R. Sletten for assistance importing samples; A. Heimsath and A. J. West for thorough reviews; and the New Zealand Department of Conservation for granting access to study sites. Data are available in the supplementary materials. I.].L. and P.C.A. designed and planned the field component of the study; I.J.L., A.E., and B.M. conducted the field sampling; A.E. described soils; and I.J.L. and J.O.S. separated ${ }^{10} \mathrm{Be}$. I.J.L. wrote the manuscript, with input from all coauthors.

\section{Supplementary Materials}

www.sciencemag.org/content/343/6171/637/suppl/DC1 Materials and Methods

Supplementary Text

Figs. S1 to S7

Tables $\mathrm{S} 1$ to $\mathrm{S7}$

References (33-92)

19 August 2013; accepted 30 December 2013

Published online 16 January 2014;

10.1126/science. 1244908 


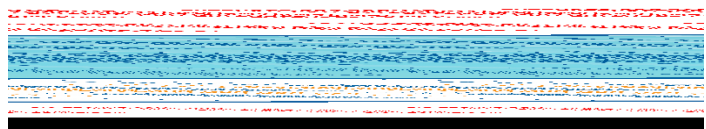

\section{Science MIAAAS}

Rapid Soil Production and Weathering in the Southern Alps, New Zealand

Isaac J. Larsen, Peter C. Almond, Andre Eger, John O. Stone, David R. Montgomery and Brendon Malcolm (January 16, 2014) Science 343 (6171), 637-640. [doi: 10.1126/science.1244908] originally published online January 16, 2014

\section{Editor's Summary}

\section{Weathering Heights}

The production of soil is the result of chemical weathering of rocks and minerals. In regions where tectonic uplift brings fresh material to Earth's surface, erosion and weathering can accelerate. Using chemical tracers, Larsen et al. (p. 637, published online 16 January; see the Perspective by Heimsath) measured soil production rates of over 2 millimeters per year in New Zealand's Southern Alps, which are some of the fastest uplifting mountains in the world. Because chemical weathering consumes $\mathrm{CO}_{2}$, these rapid rates may over time influence global climate.

This copy is for your personal, non-commercial use only.

Article Tools Visit the online version of this article to access the personalization and article tools:

http://science.sciencemag.org/content/343/6171/637

Permissions Obtain information about reproducing this article: http://www.sciencemag.org/about/permissions.dtl

Science (print ISSN 0036-8075; online ISSN 1095-9203) is published weekly, except the last week in December, by the American Association for the Advancement of Science, 1200 New York Avenue NW, Washington, DC 20005. Copyright 2016 by the American Association for the Advancement of Science; all rights reserved. The title Science is a registered trademark of AAAS. 